Document downloaded from:

http://hdl.handle.net/10251/79104

This paper must be cited as:

Castillo López, MÁ.; Aragón Revuelta, P.; Cuesta Amat, G.; Sabater Marco, C. (2006). Biodegradation of herbicide diuron by streptomycetes isolated from soil. International Biodeterioration and Biodegradation. 58(3-4):196-202. doi:10.1016/j.ibiod.2006.06.020.

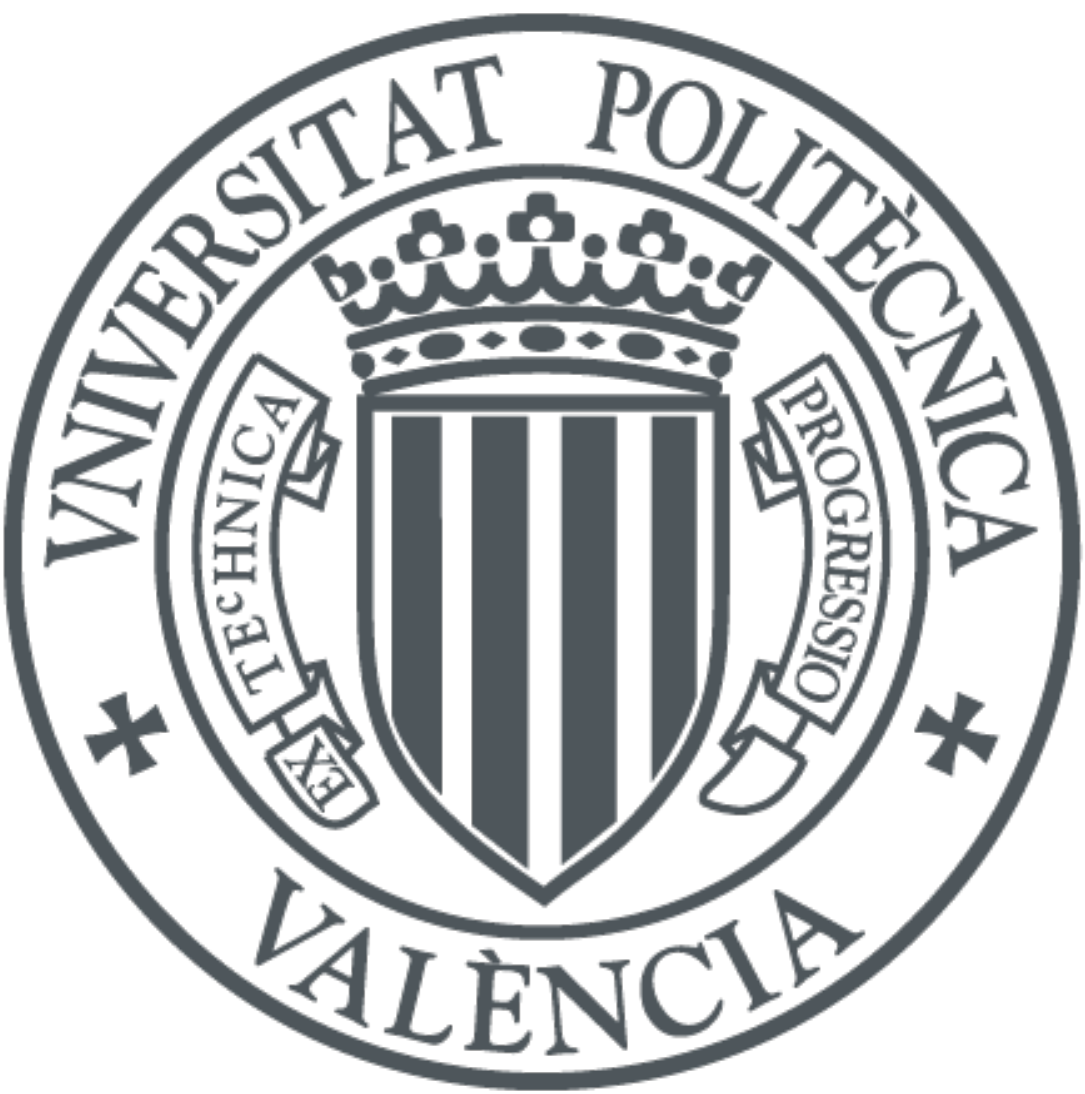

The final publication is available at

http://dx.doi.org/10.1016/j.ibiod.2006.06.020

Copyright Elsevier

Additional Information 


\title{
Biodegradation of the herbicide diuron by streptomycetes isolated from soil
}

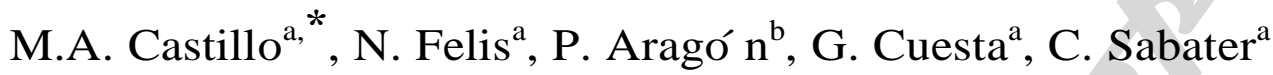

Abstract

The diuron degrading activity of 17 streptomycete strains, obtained from agricultural and non-agricultural soils, was determined in the laboratory. All strains were identified as Streptomyces sp. by phenotypic characteristics and PCR-based assays. The strains were cultivated in liquid medium with diuron $\left(4 \mathrm{mg} \mathrm{L}^{-1}\right)$ at $25 \mathrm{lC}$ for 15 days. Biodegradation activity was determined by high-performance liquid chromatography. The results indicated that all strains were able to degrade diuron, but to different amounts. Twelve strains degraded the herbicide by up to $50 \%$ and four of them by up to $70 \%$. Strain A7-9, belonging to $S$. albidofl cluster, was the most efficient organism in the degradation of diuron, achieving 95\% degradation after five days of incubation and no herbicide remained after 10 days. Overall, the strains isolated from agricultural soils exhibited higher degradation percentages and rates than those isolated from non-agricultural soils. Given the high degradation activity observed here, the streptomycete strains show a good potential for bioremediation of soils contaminated with diuron.

Keywords: Herbicide; Diuron; Actinomycetes; Streptomycetes; Soil

\section{Introduction}

Microorganisms play a significant role in the transformation and degradation of pesticides. Even the most persistent pesticides can be metabolized to some extent by microbial cultures, either by utilization of the compounds as sources of energy or nutrients, or by cometabolism with other substrates supporting microbial growth. This last process is probably the most widespread mechanism for pesticide biodegradation. Complete mineralization of pesticides or their transformation to non-toxic products is desirable, but it is more likely to be carried out by consortia of microorganisms than single isolates.

There is growing concern over the potential for contamination of soils, surface and groundwater by the repeated use of herbicides. Among the herbicides used to prevent the growth of undesirable plants, phenylurea derivatives have been widely used since their discovery in the early 1950s. One of them, diuron (3-(3,4-dichlorophenyl)-1, 1-dimethylurea), is employed widely for weed control in non-crop areas, such as roads, railways tracks, and paths, and to control weeds in a range of tree crops, such as, pear, apple, forestry, ornamental trees and pineapples, sugar cane, cotton, alfalfa and wheat (Tomlin, 2003). It kills plants by blocking electron transport at photosystem II, thus inhibiting photosynthesis.

Diuron is applied to soil, where it tends to accumulate because of its low solubility in water. DT50 in soils varies from 90-180 days (Hill et al., 1955; Tomlin, 2003); other sources indicate that it can range from one month to one year (Field et al., 2003), although values of greater than 3000 days have been reported (Madhum and Freed, 1987). The variability in calculated DT50s is likely to be due to differences in soil composition and other conditions (Gaillardon, 1996; Rouchaud et al., 2000). Degradation increases moderately in soils treated with diuron for many years. In one experiment, where soils were treated at a rate of $3 \mathrm{~kg} \mathrm{ha}^{-1}$ year $^{-1}$ for 12 years, the half-life decreased by $50 \%$ over this period, suggesting that the soil microbial community was becoming increasingly able to degrade it (Rouchaud et al., 2000). 
Much data have been collected on the direct and indirect effects of diuron on target and non-target organisms, and diuron is suspected to be genotoxic (Canna-Michaelidou and Nicolau, 1996). The US Environmental Protection Agency (EPA) has classified diuron as a 'known/likely' carcinogen since 1997. There is conflicting evidence on whether diuron can cause mutations. The National Institute for Occupational Safety and Health in the US categorized diuron as a mutagen, based on old studies (Seiler, 1978). Its use in Europe is being reviewed.

Several reports considered microbial degradation the main mechanism for dissipation of diuron from soil (Sheets, 1964; Geissbü hler et al., 1973), as well as in aquatic environments (Ellis and Camper, 1982; Howard, 1991). In a number of these studies, soil fungi have shown a high degradative activity against phenylureas, with occa- sional ability to degrade diuron (Weinberger and Bollag, 1972; Tillmanns et al., 1978; Vroumusia et al., 1996; Tixier et al., 2000), but only a few studies have found degradative activity in bacteria (Shelton et al., 1996; Esposito et al., 1998; Cullington and Walker, 1999; Tixier et al., 2001, 2002; Widehem et al., 2002). The main degradation products and pathways of diuron degradation are reviewed by Giacomazzi and Cochet (2004).

Among bacteria, actinomycetes have a considerable potential for the biotransformation and biodegradation of xenobiotics. De Schirijver and De Mot (1999) described degradation by actinomycetes of pesticides with widely different chemical structures, including organochlorines, $s$ triazines, carbamates, organophosphates, sulphonylureas and phenylureas. Other studies (Alvarez, 2003) showed that various species of actinomycetes exhibited a high capacity to degrade hydrocarbons.

Few studies have been conducted to assess the ability of actinomycetes to degrade or transform diuron. Only little data are reported about specific strains. Shelton et al. (1996) studied the ability of Streptomyces (PS1/5) to metabolize a variety of structurally different herbicides, including diuron, which was degraded by $19 \%$ after 7 days. Esposito et al. (1998) found one unique strain with a good potential for diuron degradation. More recently, other authors described Arthrobacter strains which have been able to degrade diuron (Tixier et al., 2001, 2002; Widehem et al., 2002).

The metabolic diversity of actinomycetes and their particular growth characteristics (invasive mycelial, rapid colonization of selective substrates, etc.) make them attractive organisms for bioremediation. The aim of the present study was to investigate the diuron biodegradation potential of streptomycete strains isolated from soil.

2. Material and methods

\subsection{Microbiology}

\subsubsection{Soils}

Actinomycete strains were isolated from seven different soils: two uncultivated soils and five soils from citrus orchards regularly treated with diuron. The uncultivated soils were clay loam, with $\mathrm{pH} 8$, high contents of calcium carbonate $(41 \%)$ and organic matter (5-6\%). The cultivated soils were silty loam to sandy loam, with $\mathrm{pH} 7.8-8.1$, high content of calcium carbonate $(38 \%)$ and low level of organic matter $(1.5-2 \%)$. The samples were collected from the first $10 \mathrm{~cm}$ below the surface, aseptically transferred to sterile vials and stored at $4 \mathrm{IC}$ until used

\subsubsection{Microorganisms}

A total of 53 actinomycete strains were isolated from soil using standard isolation methods. Seventeen randomly chosen strains were tested for diuron degrading ability. Twelve out of them were isolated from the agricultural soils, and five strains from two uncultivated soils. The isolates for biodegradation assay are filed at the Microbiology Laboratory of Biotechnology Department, Polytechnic University of Valencia, as shown in Table 1. The strains were maintained at 41C on ISP-2 agar medium (yeast extract, $4 \mathrm{~g}$; malt extract, $10 \mathrm{~g}$; dextrose, $4 \mathrm{~g}$; agar, $20 \mathrm{~g}$; distilled water, $1000 \mathrm{~mL}$ ). Biomass for biodegradation study was obtained after 7 days of cultivation in Petri dishes at 25 1C on ISP-2 agar medium, without any adaptation to herbicide. Five $\mathrm{mL}$ of ISP-2 liquid medium was added to the Petri dishes to obtain conidial suspensions. The final conidia concentration was estimated using a haemocytometer (improved Neubauer chamber).

\subsubsection{Phenotypic characterization of actinomycete strains}

The actinomycete strains were maintained on ISP-2 slants at $4 \mathrm{IC}$ and nutrient broth with $20 \%$ glycerol at -20 lC. In order to observe pigment production and macroscopic morphology, the isolates were cultured on International Streptomyces Project (ISP) media (Shirling and Gottlieb, 1966). Phenotypic characteristics were determined by standard procedures, described previously by Williams et al. (1989).

\subsubsection{DNA extraction and purification}

Cells were cultured on ISP-2 broth for 3-5 days, washed and collected by centrifugation and frozen for $24 \mathrm{~h}$. The thawed pellet was resuspended in $1 \mathrm{~mL}$ of TE buffer $(1 \mathrm{mM}$ EDTA, $10 \mathrm{mM}$ Tris/HCl) with glass beads $(3 \mathrm{~mm})$ and vortexed to disaggregate the clumps of mycelium. Four hundred $\mathrm{mL}$ of this suspension was incubated with $100 \mathrm{~mL}$ lysozyme $\left(50 \mathrm{mg} \mathrm{mL}^{-1}\right)$ and $15 \mathrm{~mL}$ of mutanolysine $\left(1330 \mathrm{U} \mathrm{mL}^{-1}\right)$ at $37 \mathrm{lC}$ for $30 \mathrm{~min}$ (Lanoot et al., 2005). After addition of $30 \mathrm{~mL}$ SDS (10\%), $3 \mathrm{~mL}$ proteinase $\mathrm{K}\left(20 \mathrm{mg} \mathrm{mL}^{-1}\right)$ (Sigma) and glass beads $(400 \mathrm{~mm})$, cells were vortexed and incubated at $37 \mathrm{lC}$ for $1 \mathrm{~h}$. Cell debris and polysaccharides were selectively precipitated with $\mathrm{CTAB}$ (cetyl trimethyl ammonium bromide) at $65 \mathrm{lC}$ for $10 \mathrm{~min}$. DNA was purified with equal volumes of phenol:chloroform:isoamylalcohol $(25: 24: 1)$. The suspension was shaken, centrifuged and the upper layer was removed to a clean tube. A final purification step with chloroform:isoamylalcohol $(24: 1)$ removed the residual phenol from the suspension. The upper layer was removed to a clean tube and DNA was precipitated with isopropanol. The solution was centrifuged to pellet the DNA, the supernatant was discarded and a wash step with $70 \%$ ice-cold (-20 1C) ethanol was made and the pellet was dried in vacuum. TE buffer was added to suspend the dried DNA.

\subsubsection{PCR amplification of actinomycetales/streptomyces strains}

PCR primers were designed previously and synthesized by TIB MOLBIOL (Berlin, Germany). Primers $243 \mathrm{~F}$ and A3R amplified a

Table 1

Streptomycete isolates for biodegradation assays

\begin{tabular}{ll}
\hline Origin & ${\text { Strain } \text { code }^{\mathrm{a}}}^{\text {Non-agricultural soil }}$ \\
Agricultural soil & F1-3, F1-5, F1-11, F1-12, F3-8 \\
& A1-1, A1-2, A1-5, A2-2, A2-4, A2-6, \\
& A2-11, A3-2, A3-14, A4-2, A5-3, A7-9
\end{tabular}

${ }^{a}$ All isolates are maintained in the Microbiology Laboratory of Biotechnology Department, Polytechnic University of Valencia, Spain. 
fragment of $1.25 \mathrm{~kb}$ in a wide range of actinomycetes from soil. Primers Sm6F and Sm5R amplified a $600 \mathrm{bp}$ in most of the representative members of the genus Streptomyces (Monciardini et al., 2002). The amplification reaction was carried out in a $50 \mathrm{~mL}$ reaction volume, containing $200 \mathrm{mM}$ each of the four dNTPs, $3 \mathrm{~mL}$ of genomic DNA, 1U Taq polymerase (Ecogen) with its appropriate reaction buffer, $3 \mathrm{mM} \mathrm{MgCl}_{2}$ for primers 243F/A3R and $1.5 \mathrm{mM} \mathrm{MgCl}$ for primers Sm6F/Sm5R and $1 \mathrm{mM}$ of each primer. PCRs were carried out in a thermocycler (Techne-Progene) under the following conditions: for primers $243 \mathrm{~F} / \mathrm{A} 3 \mathrm{R}$ the program was initiated by denaturation for $95 \mathrm{lC}$ for $5 \mathrm{~min}$ following by 30 cycles of $94 \mathrm{lC}$ for $45 \mathrm{~s}$, $68 \mathrm{lC}$ for $2 \mathrm{~min}$, and $72 \mathrm{lC}$ for $1 \mathrm{~min}$, one cycle of $72 \mathrm{lC}$ for $10 \mathrm{~min}$, and holding at $4 \mathrm{lC}$. For primers $\mathrm{Sm} 6 \mathrm{~F} / \mathrm{Sm} 5 \mathrm{R}$ the program was initiated by denaturation for $95 \mathrm{lC}$ for $1 \mathrm{~min}$ followed by 35 cycles of $94 \mathrm{lC}$ for $1 \mathrm{~min}$, $65 \mathrm{lC}$ for $45 \mathrm{~s}$, and $72 \mathrm{lC}$ for $1 \mathrm{~min}$, one cycle of $72 \mathrm{lC}$ for $10 \mathrm{~min}$, and holding at $4 \mathrm{1C}$. Controls without bacterial DNA were included for each reaction. Ten $\mathrm{mL}$ of total $50 \mathrm{~mL}$ PCR samples were loaded onto $1.5 \%$ agarose gels and subjected to electrophoresis for $1 \mathrm{~h}$ at 80-90 V. Amplified DNA was visualized by ethidium bromide staining under UV light. A 100 bp DNA ladder (Fermentas) was included as molecular size marker (Monciardini et al., 2002).

\subsection{Biodegradation assay}

\subsubsection{Chemicals and reagents}

Diuron standard was supplied by Riede de-Haë $n$ (Seelze, Germany) and was more than $99 \%$ pure. All solvents used were HPLC (high- performance liquid chromatography) grade. Ultrapure water was pro- duced by Milli Q system (Millipore) and Sep-Pak Silicagel cartridge was a Waters product.

\subsubsection{Biodegradation conditions}

Triplicate flasks $(500 \mathrm{~mL})$ containing $200 \mathrm{~mL}$ sterile ISP-2 medium with diuron $\left(4 \mathrm{mgL}^{-1}\right)$ were inoculated with streptomycete conidial suspension to obtain a final concentration of $1 \times 10^{6}$ conidia $\mathrm{mL}^{-1}$. Spore suspension was not added to control flasks to assess abiotic losses. Flasks were incubated at $251 \mathrm{C}$ on a rotary shaker for up 15 days. Residual diuron concentrations were measured by HPLC at regular intervals $(1,5,10$ and 15 days).

\subsubsection{Diuron analyses}

Herbicide concentrations were measured by HPLC. Samples $(25 \mathrm{~mL})$ of liquid culture were centrifuged $(5 \mathrm{~min}, 4000 \mathrm{rpm})$. The supernatant was extracted with dichloromethane $(1: 1 \mathrm{v} / \mathrm{v}, 3 \mathrm{x})$ by shaking in a separation funnel. The cell pellets were investigated for possible retention of diuron. The combined dichloromethane extracts were dehydrated with anhydrous $\mathrm{Na}_{2} \mathrm{SO}_{4}$ and evaporated to dryness under a stream of $\mathrm{N}_{2}$, and subsequently diluted to a final volume of $5 \mathrm{~mL}$ with methanol. The extract was purified through Sep-Pak Silicagel cartridges precoated with $10 \mathrm{~mL}$ of dichloromethane and $10 \mathrm{ml}$ of ethyl acetate, successively. Diuron was eluted with $4 \mathrm{~mL}$ ethyl acetate. The eluate was evaporated to dryness under stream of $\mathrm{N}_{2}$ and dissolved in $5 \mathrm{~mL}$ of methanol and reserved for chromatographic analysis.

HPLC analyses were performed using a Hewlett-Packard HP 1100 system provided with a variable wavelength UV detector G1314A. A reverse-phase column Hypersil ODS ( $125 \times 4 \mathrm{~mm}, 5 \mathrm{~mm} d_{\mathrm{p}}$ ) protected with a guard precolumn with the same phase was used throughout. The mobile phase was methanol-water $(70: 30 \mathrm{v} / \mathrm{v})$ with a flow rate of $0.8 \mathrm{~mL} \mathrm{~min}^{-1}$ and a wavelength of $254 \mathrm{~nm}$. Data were analysed with a HP-ChemStation software. Retention time of diuron under these chromatographic conditions was $3.1 \mathrm{~min}$.

Working calibration standards of diuron were prepared by serial dilution from individual stock solutions in methanol and used for spiking of liquid culture samples for recovery assays and formation of calibration plot. The calibration curve proved to be linear within a range of $0.5-$ $2 \mathrm{mg} \mathrm{L}^{-1}$. The diuron detection limit in liquid medium (at signal-tonoise ratio of $3: 1$ ) was $0.04 \mathrm{mg} \mathrm{L}^{-1}$. The recovery of the extraction and purification method was around $88 \%$.

\section{Results and discussion}

\subsection{Characterization of selected strains}

In all isolated strains a fragment of $1.25 \mathrm{~kb}$ was amplified with primers $243 \mathrm{~F}$ and $\mathrm{A} 3 \mathrm{R}$, which are targeted to a wide range of actinomycetes from soil. This set of primers has been shown to have $97 \%$ specificity for the Actinomycetales group. A $600 \mathrm{bp}$ fragment was obtained with the primers Sm6F and Sm5R, specific for Streptomyces genus. These primers have $98 \%$ specificity for this genus (Monciardini et al., 2002).

Phenotypic and morphological studies on selected strains revealed a typical pattern in members of Streptomyces genus. They develop aerial mycelium on sporulation media. The taxonomy of Streptomyces remains confused and the definition of species is unresolved, due to the great variety of morphological, cultural, physiological and biochemical characteristics that are observed both at inter- and intraspecies level. This emphasizes the importance of the polyphasic taxonomy approach, which can only be maintained by standardization (Goodfellow, 1997; Anderson and Wellington, 2001). This is why we have applied the methods recommended in the International Streptomyces Project (Shirling and Gottlieb, 1966), which is the basis of the classification of the genus Streptomyces in Bergey's Manual of Systematic Bacteriology (Williams et al., 1989). These phenotypic studies allowed an affiliation of the selected strains to the major clusters described by Williams et al. (1989) (Table 2).

\subsection{Biodegradation studies}

The results of biodegradation, expressed as percentage of depletion of diuron, estimated by HPLC at regular intervals, are shown in Table 3 . The results indicate that all strains tested were able to degrade diuron, but with different degradation percentages. There was no evidence of diuron degradation by abiotic losses in control flasks. Moreover, extraction of cell pellets with dichloromethane showed that no diuron retention occurred in cells.

Among the strains tested, A7-9 appeared to be the most efficient for the degradation of diuron, achieving $53.7 \%$ degradation after one day's incubation, $95.6 \%$ after five days and no herbicide remained after 10 days' incubation. Strains A1-1, A1-2, A2-4, A2-6 and A2-11 were also efficient, degrading more than $50 \%$ diuron by day 5 , and reaching higher percentages at the end of the assays. These strains were isolated from agricultural soils which had received some treatment with diuron and other herbicides, indicating the ability of the organisms to adapt to the environmental conditions. On the other hand, the strains isolated from non-agricultural soils had degraded less than $50 \%$ diuron by day 5, although strains F1-11, F1-5 and F38 achieved up to $50 \%$ degradation at the end of the assays $(70.8 \%, 52.2 \%$ and $51 \%$, respectively). Overall, the diuron degradation percentage of the strains isolated from 
Table 2

Phenotypic characterization of Streptomyces strains

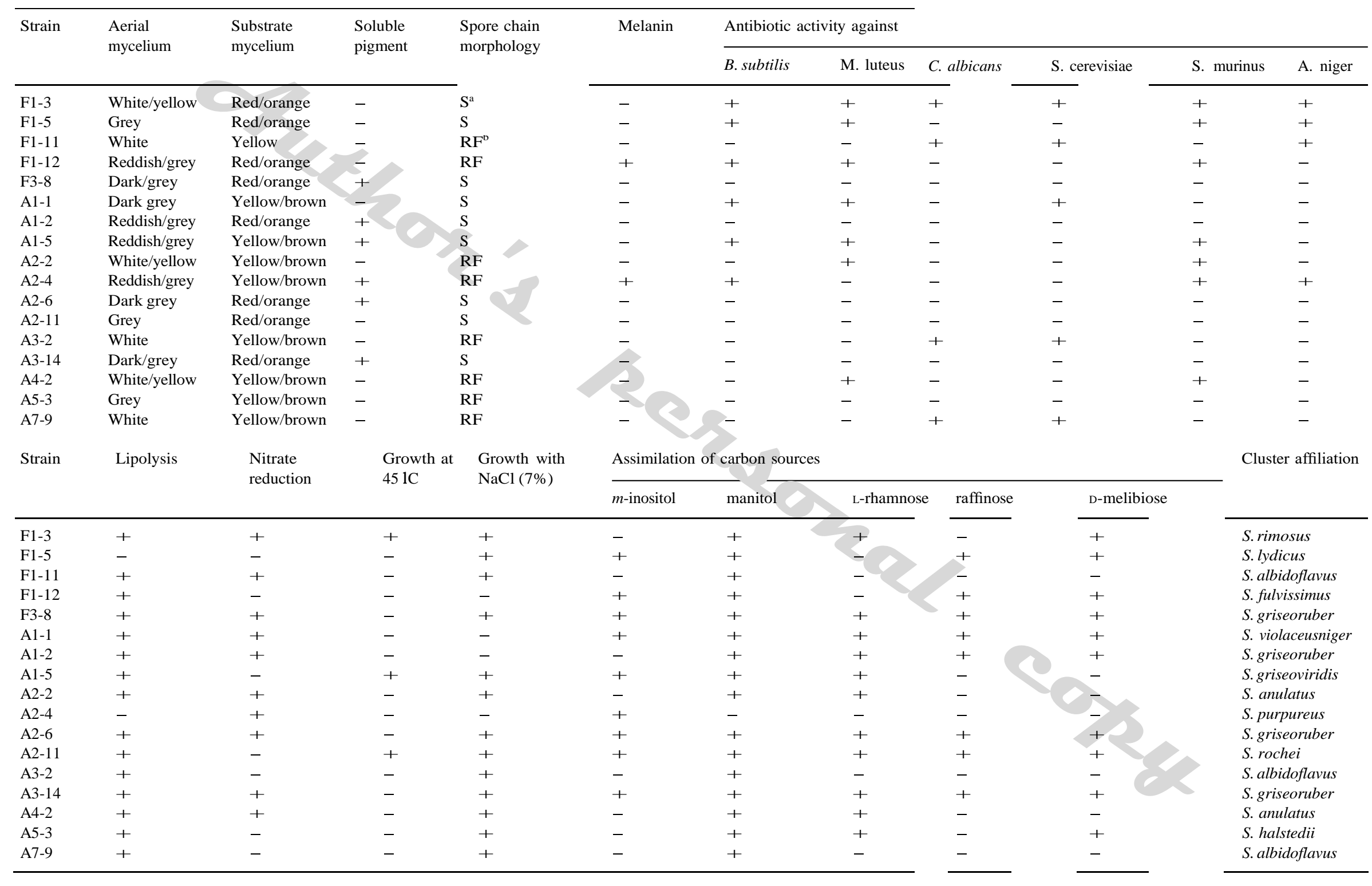

${ }^{\text {a }} \mathrm{S}$, spiral

${ }^{b} \mathrm{RF}$, rectiflexible. 
Table 3

Disappearance of diuron $(\%)^{\mathrm{a}}$ in the presence of Streptomyces strains in pure cultures, initial concentration $4 \mathrm{mg} \mathrm{L}^{-1}$

\begin{tabular}{lrrrr}
\hline Strain & \multicolumn{1}{l}{ 1 day } & \multicolumn{1}{l}{ 5 days } & \multicolumn{1}{l}{10 days } & \multicolumn{1}{l}{15 days } \\
\hline F1-3 & 25.872 .4 & 31.772 .0 & 38.672 .5 & 42.371 .3 \\
F1-5 & 40.771 .0 & 42.771 .5 & 46.371 .2 & 52.272 .7 \\
F1-11 & 26.172 .5 & 45.973 .7 & 62.371 .9 & 70.871 .6 \\
F1-12 & 20.671 .1 & 30.671 .1 & 35.771 .1 & 46.572 .0 \\
F3-8 & 18.272 .1 & 20.771 .2 & 36.571 .1 & 51.072 .6 \\
A1-1 & 39.671 .0 & 53.271 .5 & 68.571 .1 & 72.171 .6 \\
A1-2 & 42.271 .4 & 56.971 .2 & 63.271 .6 & 63.971 .6 \\
A1-5 & 41.171 .4 & 43.771 .3 & 51.271 .4 & 62.971 .4 \\
A2-2 & 28.271 .9 & 42.072 .1 & 47.972 .0 & 62.071 .4 \\
A2-4 & 48.172 .6 & 52.171 .3 & 70.072 .1 & 71.270 .3 \\
A2-6 & 33.771 .2 & 56.272 .3 & 57.272 .3 & 64.771 .7 \\
A2-11 & 43.571 .6 & 60.971 .3 & 66.971 .6 & 68.171 .5 \\
A3-2 & 38.571 .1 & 41.271 .3 & 43.374 .3 & 47.175 .3 \\
A3-14 & 0.070 .0 & 9.071 .4 & 31.271 .3 & 43.171 .5 \\
A4-2 & 38.771 .1 & 41.370 .6 & 44.071 .3 & 45.570 .5 \\
A5-3 & 40.171 .6 & 42.972 .1 & 61.971 .6 & 67.071 .6 \\
A7-9 & 53.772 .4 & 95.672 .5 & 100.070 .0 & 100.070 .0 \\
\hline
\end{tabular}

${ }^{\mathrm{a}}$ Mean of three values7standard deviation.

agricultural soils was always higher than those isolated from non-agricultural soils.

The diuron biodegradation rate of 17 strains of streptomycetes was calculated and the results are shown in Table 4. Strains A7-9 and A2-11 were the fastest degraders, with similar half-lives $(0.7$ and 1.4 days, respectively). Although A2-11 was able to degrade half of the diuron in 1.4 days, its degradation efficiency was lower than that observed for strain A7-9, since $32 \%$ of diuron still remained intact after 15 days. Strains A2-4, A1-2 and A1-1 exhibited a similar degradative behaviour, with halflives less than 5 days $(2.2,2.9$ and 3.7 days, respectively) and not achieving total degradation of diuron by the end of assay. The half-life of strains A2-6, A5-3, A1-5 and A2-2 was slightly higher (5-9 days) and the degradation can be considered more gradual. It is interesting to note that one non-agricultural isolate (F1-11) showed a half-life of 6.4 days, comparable to agricultural isolates, although the highest diuron degradation rate corresponded mainly to strains isolated from agricultural soils. These results suggest that strains isolated from soils regularly treated with herbicide have a considerable potential for biodegradation, since the organisms are adapted to pesticide presence. This is in line with Widehem et al. (2002), who isolated and characterized one actinobacteria strain, Arthrobacter sp. N2, from a long-term diuron contaminated soil. This strain was able to degrade diuron completely, suggesting microbial adaptation to herbicide metabolism.

During our biodegradation studies, one unidentified HPLC peak, concomitant with the disappearance of diuron, was observed in the chromatograms of F1-11 and A2-4 strains. According to the literature, we could expect that this product corresponds either to the main metabolite of diuron biodegradation, 3,4-dichloroaniline, or to the
Table 4

Biodegradation rate parameters for diuron in pure cultures of Streptomyces strains, initial concentration $4 \mathrm{mg} \mathrm{L}^{-1}$

\begin{tabular}{|c|c|c|c|}
\hline Strain & Regression equation ${ }^{\mathrm{a}, \mathrm{b}}$ & $R^{2}$ & Half-life (Days) \\
\hline F1-3 & $y \quad 1 / 4 \mathrm{e}^{(4.31587-0.0181151 x)}$ & 0.9193 & 22.3 \\
\hline F1-5 & $y \quad 1 / 4 \mathrm{e}^{(4.11371-0.0154032 x)}$ & 0.8602 & 13.1 \\
\hline F1-11 & $y \quad 1 / 4 \mathrm{e}^{(4.34204-0.0669697 x)}$ & 0.9775 & 6.4 \\
\hline $\mathrm{F} 1-12$ & $y \quad 1 / 4 \mathrm{e}^{(4.39645-0.0267647 x)}$ & 0.9590 & 18.1 \\
\hline F3-8 & $y \quad 1 / 4 \mathrm{e}^{(4.12174-0.01550 x)}$ & 0.7778 & 15.2 \\
\hline A1-1 & $y \quad 1 / 4 \mathrm{e}^{(4.12674-0.0574754 x)}$ & 0.9490 & 3.7 \\
\hline A1-2 & $\begin{array}{lll}y & 1 / 4 & \mathrm{e}^{(4.00593-0.0327392 x)} \\
y & 1 / 4 & \mathrm{e}^{(4.15663-0.0329325 x)}\end{array}$ & 0.8117 & 2.9 \\
\hline A1-5 & $\begin{array}{lll}y & 1 / 4 & \mathrm{e}^{(4.15663-0.0329325 x)} \\
y & 1 / 4 & \mathrm{e}^{(4.31274-0.0429261 x)}\end{array}$ & 0.9084 & 7.4 \\
\hline A2-2 & 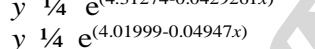 & 0.9512 & 9.3 \\
\hline A2-4 & $y \quad 1 / 4 \mathrm{e}^{(4.13322-0.04205 x)}$ & 0.8559 & 2.2 \\
\hline A2-6 & $y \quad 1 / 4 \mathrm{e}^{(3.96774-0.0390319 x)}$ & 0.8017 & 5.3 \\
\hline A2-11 & $y \quad 1 / 4 \mathrm{e}^{(4.14448-0.01406 x)}$ & 0.8106 & 1.4 \\
\hline A3-2 & $y 1 / 4 \mathrm{e}^{(4.67398-0.0422027 x)}$ & 0.8178 & 16.5 \\
\hline A3-14 & $y \quad 1 / 4 \mathrm{e}^{(4.11715-0.00834766 x)}$ & 0.9791 & 18.1 \\
\hline A4-2 & $y \quad 1 / 4 \mathrm{e}^{(4.18217-0.0470733 x)}$ & 0.9087 & 24.6 \\
\hline A5-3 & $y^{1 / 4} 42.3888-17.9689 \ln x$ & 0.9218 & 5.7 \\
\hline A7-9 & & 0.9043 & 0.7 \\
\hline \multicolumn{4}{|c|}{$R^{2}:$ Cerrelation coefficient squared (Po0.05). } \\
\hline
\end{tabular}

demethylation products (Ellis and Camper, 1982; Cullington and Walker, 1999; Tixier et al., 2000; Widehem et al., 2002). On the other hand, there was no evidence of any other HPLC peak different from diuron in the chromatograms of the other strains. The herbicide might be further transformed into metabolites not detected with the analytical method used, or even mineralized.

Further studies to optimize the diuron degradation conditions in the soil must be carried out. Since previous studies have shown that Streptomyces strains can degrade a variety of pesticides, it is not unreasonable to expect that they will also do so in the soil. Cullington and Walker (1999) observed the rapid degradation of diuron in soils when a single bacterium, able to degrade it under laboratory conditions, was added, and suggested that rapid herbicide biodegradation could occur in the soil.

Many of the degradation compounds of diuron exhibit a higher toxicity than the parent compound (Tixier et al., 2000, 2001). However, their further biodegradation, either by fungi or bacteria, has been reported in many studies (Tixier et al., 2002; Travkin et al., 2003). In soils, a wide range of microorganisms are present, and we can expect that the simultaneous action of various microorganisms will succeed in degrading these compounds (El-Fantroussi, 2000; Sorensen et al., 2003; Barra-Caracciolo et al., 2005). It is likely that diuron could be transformed sequentially by different strains in soil habitats, including Streptomyces strains, other actinobacteria and fungi.

This study complements the results obtained by other authors, since a large number of Streptomyces strains have shown diuron degradative activity. Our results suggest the 
importance of a continuous search for new strains with degradative activity given the high degradation rates observed. They could be used efficiently in bioremediation of pesticide-polluted soils, since they easily survive and proliferate as a consequence of their mycelial growth and great potential metabolic diversity. The ability of many Streptomyces strains to be genetically engineered is another attractive feature. However, it is necessary to study their adaptation and understand the control of expression of catabolic genes in their natural environment (Cases and de Lorenzo, 2005).

\section{References}

Alvarez, H.M., 2003. Relationship between b-oxidation pathway and the hydrocarbon-degrading profile in actinomycete bacteria. International Biodeterioration \& Biodegradation 52, 35-42.

Anderson, A.S., Wellington, E.M.H., 2001. The taxonomy of Streptomyces and related genera. International Journal of Systematic and Evolutionary Microbiology 51, 797-814.

Barra-Caracciolo, A., Giuliano, G., Grenni, P., Guzzella, L., Pozzoni, F., Botó n, P., Fava, L., Crobe, A., Orrù , M., Funari, E., 2005. Degradation and leaching of the herbicides metalochlor and diuron: a case study in an area of Northern Italy. Environmental Pollution 134, 525-534.

Canna-Michaelidou, S., Nicolau, A.S., 1996. Evaluation of the genotoxicity potential (by Mutatox ${ }^{\mathrm{TM}}$ test) of ten pesticides found as water pollutants in Cyprus. Science of the Total Environment 193, 27-35.

Cases, I., de Lorenzo, V., 2005. Genetically modified organisms for the environment: stories of success and failure and what we have learned from them. International Microbiology 8, 213-222.

Cullington, J.E., Walker, A., 1999. Rapid biodegradation of diuron and other phenylurea herbicides by a soil bacterium. Soil Biology and Biochemistry 31, 677-686.

De Schirijver, A., De Mot, R., 1999. Degradation of pesticides by actinomycetes. Critical Reviews in Microbiology 25, 85-119.

El-Fantroussi, S., 2000. Enrichment and molecular characterization of a bacterial culture that degrades methoxy-methyl urea herbicides and their aniline derivates. Applied Environmental Microbiology 66, $5110-5115$

Ellis, P.A., Camper, N.D., 1982. Aerobic degradation of diuron by aquatic microorganisms. Journal of Environmental Science and Health Part B: Pesticides, Food Contaminants and Agricultural Wastes 17, 277-289.

Esposito, E., Paulillo, S.M., Manfio, G.P., 1998. Biodegradation of the herbicide diuron in soil by indigenous actinomycetes. Chemosphere 37 , 541-548.

Field, J.A., Reed, R.L., Sawyer, T.E., Griffiths, S.M., Wigington, P.J., 2003. Diuron occurrence and distribution in soil and surface and ground water associated with grass seed production. Journal of Environmental Quality 32, 171-179.

Gaillardon, P., 1996. Influence of soil moisture on long-term sorption of diuron and isoproturon by soil. Pesticide Science 47, 347-354.

Geissbü hler, H., Martin, H., Voss, G., 1973. The substituted ureas. In: Kerany, P.C., Kaufman, D.D. (Eds.), Herbicide Chemistry, Degrada- tion and Mode of Action, vol. 1, second ed. MarcelDecker, New York, pp. 209-291.

Giacomazzi, S., Cochet, N., 2004. Environmental impact of diuron transformation: a review. Chemosphere 56, 1021-1032.

Goodfellow, M., 1997. Actinomycete systematics. An unfinished synthesis. In: 10th International Symposium on the Biology of Actinomycetes, ISBA'97, May 27-30, 1997. Chinese Pharmaceutical Association, Chinese Society Microbiology.

Howard, P.H., 1991. Handbook of Environmental Fate and Exposure Data for Organic Chemicals. Lewis Publishers, Chelsea.
Hill, G.D., McGahen, J.W., Baker, H.M., Finnerty, D.W., Bingeman, C.W., 1955. The fate of substituted urea herbicides in agricultural soils. Agronomy Journal 47, 93-104.

Lanoot, B., Vancanneyt, M., Van Schoor, A., Liu, Z., Swings, J., 2005. Reclassification of Streptomyces nigrifaciens as a later synonym of Streptomyces flavovirens; Streptomyces citreofluorescens, Streptomyces chrysomallus subsp. chrysomallus and Streptomyces fluorescens as later synonyms of Streptomyces anulatus; Streptomyces chibaensis as a later synonym of Streptomyces corchorusii; Streptomyces flaviscleroticus as a later synonym of Streptomyces minutiscleroticus and Streptomyces lipmanii, Streptomyces griseus subsp. alpha, Streptomyces griseus subsp. cretosus and Streptomyces willmorei as later synonyms of Streptomyces microflavus. International Journal of Systematic Evolutionary Microbiology 55, 729-731.

Madhum, Y.A., Freed, V.H., 1987. Degradation of the herbicides bromacil, diuron and chlortoluron in soil. Chemosphere 16, 10031011.

Monciardini, P., Sosio, M., Cavaletti, L., Chiocchini, C., Donadio, S., 2002. New PCR primers for the selective amplification of 16 S rDNA from different groups of actinomycetes. FEMS Microbiology Ecology $42,419-429$.

Rouchaud, J., Neus, O., Bulcke, K., Cools, K., Eelen, H., Dekkers, T., 2000. Soil dissipation of diuron, chlorotoluron, simazine, propyzamide and diflufenican herbicides after repeated applications in fruit tree orchards. Archives of Environmental Contamination and Toxicology $39,60-65$.

Seiler, J.P., 1978. Herbicidal phenylalkylureas as possible mutagens I. Mutagenicity tests with some urea herbicides. Mutation Research 58, 353-359.

Sheets, T.J., 1964. Review of disappearance of substituted urea herbicides from soil. Journal of Agricultural and Food Chemistry $12,30-33$

Shelton, D.R., Khader, S., Karns, J.S., Pogell, B.M., 1996. Metabolism of twelve herbicides by Streptomyces. Biodegradation 7, 129-136.

Shirling, E.B., Gottlieb, D., 1966. Methods for characterization of Streptomyces species. International Journal of Systematic Bacteriology $16,313-340$.

Sorensen, S.R., Bending, G.D., Jacobsen, C.S., Walker, A., Aamand, J., 2003. Microbial degradation of isoproturon and related phenylurea herbicides in a below agricultural fields. FEMS Microbiology Ecology $45,1-11$.

Tillmanns, G.M., Wallnö fer, P.R., Engelhardt, G., Olie, K., Hutzinger, O., 1978. Oxidative dealkylation of five phenylurea herbicides by the fungus Cunninghamella echinulata (Thaxter). Chemosphere 1, 59-64.

Tixier, C., Bogaerts, P., Sancelme, M., Bonnemoy, F., Twagilimana, L., Cuer, A., Bohatier, J., Veschambre, H., 2000. Fungal biodegradation of a phenylurea herbicide, diuron: structure and toxicity of metabolites. Pest Management Science 56, 455-462.

Tixier, C., Sancelme, M., Bonnemoy, F., Cuer, A., Veschambre, H., 2001. Degradation products of a phenylurea herbicide, diuron: synthesis, ecotoxicity, and biotransformation. Environmental Toxicology and Chemistry 20, 1381-1389.

Tixier, C., Sancelme, M., Aı̈t- Aïssa, S., Widehem, P., Bonnemoy, F., Cuer, A., Truffaut, N., Veschambre, H., 2002. Biotransformation of phenylurea herbicides by a soil bacterial strain, Arthrobacter sp. N2: structure, ecotoxicity and fate of diuron metabolite with soil fungi. Environmental Toxicology and Chemistry 20, 1381-1389.

Tomlin, C., 2003. The Pesticide Manual, 13th ed. British Crop Protection Council, Farnham, Surrey, UK.

Travkin, V.M., Solyanikova, I.P., Rietjens, I.M., Vervoot, J., van Berkel, W.J., Golovleva, L.A., 2003. Degradation of 3,4-dichloro- and 3,4difluoroaniline by Pseudomonas fluorescens 26-K. Journal of Environmental Science and Health B 38, 121-132.

Vroumusia, T., Steiman, R., Seigle-Murandi, F., Benoit-Guyod, J.L., Khadrani, A., 1996. Biodegradation of three substituted phenylurea herbicides (chlortoluron, diuron, and isoproturon) by soil fungi. A comparative study. Chemosphere 33, 2045-2056. 
Weinberger, M., Bollag, J.M., 1972. Degradation of chlorbromuron and related compounds by the fungus Rhizotocnia solani. Applied Microbiology 24, 750-754.

Widehem, P., Aït-Aïsa, S., Tixier, C., Sancelme, M., Veschambre, H., Truffaut, N., 2002. Isolation, characterization and diuron transforma- tion capacities of a bacterial strain Arthrobacter sp. N2. Chemosphere $46,527-534$.

Williams, S.T., Sharpe, M.E., Holt, J.G. (Eds.), 1989. Bergey's Manual of Systematic Bacteriology, vol. 4. Williams \& Wilkins, Baltimore. 